\title{
STRESNI ODGOVOR U DEČJEM UZRASTU
}

\section{Sažetak}

Uvod: Stres je proces koji se odigrava u organizmu kada je on izložen bilo kakvoj agresiji, koja u takvoj meri ugrožava njegovo stanje da odbrana korišćenjem specifičnih adaptacionih mehanizama nije moguća. Adaptacione sposobnosti svake individue su ograničene i različite, a zavise od brojnih činilaca, kao što su uzrast, pol, zdravstveno stanje i brojne psihičke i socijalne karakteristike. Preduslov adekvatnog odgovora na stres je postojanje intaktnosti i funkcionalne zrelosti tj. kompetentnosti hipotalamusno-hipofizno-adrenalne osovine.

Cilj: Sagledavanje karakteristika stresnog odgovora od najranijeg uzrasta je cilj ovog rada.

Materijal i metodi rada: Prikaz dosadašnjih saznanja o karakterstikama adrenalne osovine i stresnog odgovora kod novorođenčadi.

Rezultati: Danas je poznato da je odgovor adrenalne osovine na stres kod novorođenčeta na rođenju kvalitativno prisutan i kod ročne novorođenčadi kvantitativno kompetentan, kao što je to slučaj i u kasnijim periodima detinjstva, gde odgovor na stres ne pokazuje značajne razlike u zavisnosti od uzrasta, dok je kod prevremeno rođene novorođenčadi ovaj odgovor slabiji. Poznavajući specifične okolnosti prematuriteta, jasno je da se prevremeno rođeno novorođenče, naročito ono veoma male telesne mase, počevši još in utero, zapravo stalno nalazi u određenom stanju stresa. Prema rezultatima brojnih istraživanja, čini se, da su u situacijama stresa neka veoma prematurna novorođenčad nesposobna da adaptiraju svoju sekreciju kortizola, što ih dovodi u stanje relativne adrenalne insuficijencije, koja je tranzitornog karaktera. Počev od druge nedelje života sekrecija kortizola počinje da se adaptira. Koliko god je sa jedne strane od vitalnog značaja adekvatan odgovor u stresu, toliko u stanju intenzivnog i dugotrajnog stresa, ovaj odgovor prestaje da bude svrsishodan i može da ima negativnog upliva na stanje novorođenčeta. 
Zaključak: Neadekvatan stresni odgovor je faktor koji doprinosi razvoju patološkog stanja kod prevremeno rođenog novorođenčeta. Osim neposrednih, od značaja su i kasne posledice stresa, o kojima se sve više izveštava, što nameće potrebu prevencije stresa kod ove dece, kao put ka poboljšanju ishoda ove najvulnerabilnije populacije.

Ključne reči: stres, kortizol, prevremeno rođeno novorođenče

\section{Abstract}

Introduction: Stress is a process that takes place when the body is exposed to any kind of aggression, which in such a way threatens it, that defense using specific adaptation mechanisms is not possible. The adaptive abilities of each individual are limited and different, depending on a number of factors, such as age, sex, health status and numerous psychological and social characteristics. The precondition for an adequate response to stress is the existence of intactness and functional maturity and the competence of the hypothalamic-pituitary-adrenal axis.

Objective: The aim of this paper is to investigate the characteristics of the stress response from the earliest age of life.

Material and methods: An overview of current knowledge of the adrenal axis and stress response in newborns.

Results: Nowdays it is known that the response of the adrenal axis to stress in newborns at birth is qualitatively present, and in the case of a term newborn, it is quantitatively competent, as it is in the later periods of childhood, when the response to stress does not show a significant age related difference. In premature infants this response is weaker. Knowing the specificity of prematurity, it is clear that premature newborns, especially those very low birth weigh, are actually constantly in a certain state of stress initiated in utero. According to the results of numerous studies, it seems that in stress situations some very premature newborns are unable to adapt their secretion of cortisol, which leads them to a state of relative adrenal insufficiency, which is of a transient character - from the second week of life, the secretion of cortisol begins to adapt. However much of vital importance is an adequate response to stress in the state of intense and long-lasting stress, when this response ceases to be purposeful and may have a negative impact on the health of the newborn.

Conclusion: Inadequate stress response is a factor that contributes to the development of a pathological condition in a premature newborn. In addition to immediate, significant late consequences of stress are increasingly reported, which imposes the need to prevent stress in these children, as a way to improve the outcome of this most vulnerable population.

Key words: stress, cortisol, premature newborn 
Po definiciji Selye-a, stres je opšta reakcija, tj. skup nespecifičnih reakcija organizma, na bilo koji zahtev za prilagođavanje izmenjenim uslovima spoljašnje sredine, čiji je cilj održavanje homeostaze, koja je neophodna za preživljavanje. Ovaj “opšti adaptacioni sindrom" je proces koji se odigrava u organizmu kada je on izložen bilo kakvoj agresiji, koja u takvoj meri ugrožava njegovo dotadašnje stanje da odbrana korišćenjem samo pojedinih specifičnih adaptacionih mehanizama nije moguća.

Stresni odgovor se odvija preko adrenalne osovine i osovine simpatikus-srž nadbubrežne žlezde i ova reakcija je gotovo uvek ista, stereotipna, bez obzira o kakvom je stresoru reč.

Ipak, stresne reakcije se ne mogu svesti samo na prethodne sterotipne promene i procese, već postoje različiti obrasci neuroendokrinih, psihičkih, imunoloških i drugih promena u stresu.

Adaptacione sposobnosti svake individue su ograničene i različite, kao i specifične za razne vidove stresnih situacija, a zavise od brojnih činilaca, kao što su napr. uzrast, pol, zdravstveno stanje i brojne psihičke i socijalne karakteristike ličnosti, zbog čega se kaže da je stres visoko personalizovan ili individualan proces (1).

Mozak, kao organ psihe i istovremeno glavni regulator i koordinator rada telesnih organa, ima centralnu ulogu i u procesima koji se odvijaju u stresu. Stresori iz spoljašnje i unutrašnje sredine deluju na mozak putem osećaja i opažanja, povezanih sa prethodnim iskustvom u funkciji utvrđivanja značaja stresnih činilaca u ugrožavanju organizma. Od ovog "inputa" zavisi i "output" koji pokreće niz kompleksnih promena u organizmu u cilju adaptacije na novonastalu situaciju.

Aktiviranje adrenalne osovine u stresu, koja je u suštini neuroendokrini sistem, dakle, počinje od CNS-a, pa hormonalnom kaskadom koja pojačava signal, preko hipotalamusa, hipofize do kore nadbubrežne žlezde, odakle se luče glukokortikoidi, najvažniji hormoni sistema, koji su, oslobođeni u opštu cirkulaciju, delujući na traget tkiva, odgovorni za većinu fizioloških promena koje se sreću i od značaja su u stresu.

Preduslov adekvatnog odgovora novorođenčeta na stres, između ostalog, je postojanje intaktnosti i funkcionalne zrelosti tj. kompetentnosti hipotalamusno-hipofizno-adrenalne osovine.

Maturacija humane fetalne adrenalne funkcije je složen proces koji podrazumeva čitav niz serijskih međusobnih zbivanja u nadbubrežnoj žlezdi, hipofizi, hipotalamusu i perifernim tkivima. Ovaj proces progresivno napreduje tokom intrauterusnog života i može se posmatrati grubo kroz tri faze: embriogenezu, hipotalamusnu maturaciju i maturaciju funkcije adrenalnog sistema (2).

Razvoj adrenalnog sistema nije završen na rođenju i određene promene pojedinih delova ovog sistema, kako u morfološkom tako i funkcionalnom smislu, dešavaju se i nakon rođenja.

Najznačajnije morfološke promene odvijaju se u nadbubrežnoj žlezdi, čiji postnatalni razvoj karakteriše brza involucija fetalne kore, koja počinje neposredno po rođenju. 
Cirkadijalni ritam, kao bitna funkcionalna karakteristika većine neuroendokrinih sistema, u lučenju CRH, ACTH i kortizola nije prisutan u fetusa ni u novorođenčeta (3). U toku intrauterusnog života melatonin iz epifize majke ima ključnu ulogu u ovom ciklusu. Kod novorođenčeta, ovaj ritam se razvija u sklopu procesa njegove adaptacije na ekstrauterusni život, koji počinje rođenjem, i nastavlja se u prvim postnatalnim danima i nedeljama (od 8. do 12. ned.). Potpuni cirkadijalni ritam adrenalne osovine se razvija tokom druge godine života $(4,5)$.

Stres predstavlja još jedan mehanizam kontrole sekrecije $u$ adrenalnom siste$\mathrm{mu}$, koji kao i cirkadijalni ritam, takođe, deluje nezavisno od mehanizma negativne povratne sprege (6).

U pogledu odgovora na pitanje da li kod novorođenčadi postoji ovaj mehanizam, u medicinskoj literaturi od ranije postoje različiti podaci i izveštaji, od onih koji pokazuju da odgovor adrenalne osovine na stres postoji još in utero $(7,8)$, tj. da na rođenju pokazuje svoju potpunu maturaciju $(9,10)$, do onih koji sugerišu da u određene kategorije novorođenčadi odgovor na stres izostaje (11), ili je on nedovoljan $(12,13,14)$.

Danas je poznato da je odgovor adrenalne osovine na stres kod novorođenčeta na rođenju kvalitativno prisutan i kod (zdrave) ročne novorođenčadi (uglavnom) kvantitativno kompetentan, kao što je to slučaj i u kasnijim periodima detinjstva, gde prema nekim istraživanjima, odgovor na stres ne pokazuje značajne razlike u zavisnosti od uzrasta (15), dok je kod prevremeno rođene novorođenčadi ovaj odgovor slabiji $(5,16)$.

U prilog adekvatnog odgovora na stres kod ročne novorođenčadi govore visoke vrednosti kortizola na rođenju (stres rađanja) i tokom prva tri dana (postnatalna adaptacija), a ove vrednosti su različite kod različitih načina porođaja (patološke prezentacije, instrumentalni porođaj, carski rez), takođe i u različitim patološkim stanjima (asfiksija, infekcija, hipoglikemija..) $(5,17,18,19,20)$.

Poznavajući specifične okolnosti prematuriteta, jasno je da se prevremeno rođeno novorođenče, naročito ono veoma male telesne mase, počevši neretko još in utero, zapravo stalno nalazi u određenom stanju stresa. Naime prematuritet nije fiziološka situacija, on je sam po sebi stres (5).Vrednosti kortizola kod ove novorođenčadi su u obrnutoj korelaciji sa gestacijskom dobi $(21,22)$.

U brojnim istraživanjima nađeni su identični nivoi kortizola kod bolesne prevremeno rođene novorođenčadi i one zdrave i zaključena je nedovoljnost sekrecije kortizola kod bolesne prevremeno rođene novorođenčadi $(16,23)$. I u našoj studiji iz 2004., pokazano je da prevremeno rođena novođenčad imaju manji kortizolski odgovor na asfiksiju u odnosu na ročnu novorođenčad, a takođe da su vrednosti kortizola kod ove novorođenčadi sa težom kliničkom slikom slične onima kod dece koja su u boljoj kondiciji, odnosno da je razlika statistički nesignifikantna (5). Limitiranost sinteze kortizola, prema raznim istraživanjima, biće da potiče, delom od enzimske nezrelosti nadbubrežne žlezde (11ß-hidroksilaze) $(13,24)$ i delom od 
insuficijencije stimulacije, porekla vezanog za hipotalamus, prema nekim autorima, nesposobnosti neke prevremeno rođene novorođenčadi da prepoznaju i/ili odgovore na stresne situacije $(11,25)$, dok je odgovor hipofize prevremeno rođenog novorođenčeta čini se, adaptiran na situacije stresa (26).

U svetlu svih ovih rezultata, čini se, da su u situacijama stresa neka veoma prematurna novorođenčad nesposobna da adaptiraju svoju sekreciju kortizola, što ih dovodi u stanje relativne adrenalne insuficijencije. Ova tranzitorna adrenalna insuficijencija je povremeno povezana sa kliničkim znacima insuficijencije nadbubrežne žlezde (hipotenzija, hiponatrijemija sa gubitkom soli, acidoza) i biološki gledano, sa niskim vrednostima kortizolemije tokom prve nedelje života (27). Počev od druge nedelje života sekrecija kortizola počinje da se adaptira, nakon jedne faze maturacije adrenalne osovine $(11,28)$.

$\mathrm{Na}$ osnovu dosadašnjih saznanja o karakteristikama adrenalnog sistema i kortizolskog odgovora kod novorođenčadi izvesno je da ponekad neadekvatan, nedovoljan odgovor na stres, zbog razvojne nezrelosti adrenalnog sistema, ugrožava prevremeno rođeno novorođenče i doprinosi njegovom teškom stanju, a kako se razmatra, moguće ima značaja i u genezi određene patologije (BPD) (29).

Koliko god je sa jedne strane od vitalnog značaja adekvatan odgovor u stresu, toliko u stanju intenzivnog i dugotrajnog stresa, ovaj odgovor prestaje da bude svrsishodan i može da ima negativnog upliva na stanje novorođenčeta (4).

Kako je kortizolski odgovor određen kvantitetom stresa $(5,26)$, u stanjima intenzivnog stresa naglo dolazi do porasta koncentracije kortizola u krvi, koja može da se poveća i do deset puta, čime se ispoljavaju i njegovi negativni efekti (1), što predstavlja dodatni momenat produbljivanja najčešće već prethodno kritičnog stanja novorođenčeta.

Ukoliko se stres ponavlja sukcesivno, jedan za drugim, ne dolazi do povećanja kortizolskog odgovora sa narednim stresom, što znači da je stres vezan za određen stepen odgovora adrenalne osovine. Vreme između ponovljenih stresova mora biti najmanje 90 min da bi se dobio određeni odgovor ACTH i kortizola na stres. Smatra se da kortizol blokira ponovni odgovor na stres delujući na glukokortikoidne receptore u CNS-u. U tom smislu ponavljanje stresnih situacija dovodi do insuficijentnog adrenalnog odgovora, što sa jedne strane može imati odgovarajuće posledice, a sa druge strane možda upravo predstavlja i protektivni mehanizam od suviška kortizola?! Takođe, kako hormoni ne stoje neprekidno na raspolaganju, kora nadbubrežne žlezde ne skladišti glukokortikoide, već ih stvara na zahtev tj. dati signal, potrebno je nešto više od tri minuta da bi se na stimulus povećala koncentracija kortizola u krvi, nakon čega se održava više desetina minuta. To čini ovaj sistem u izvesnoj meri inertnim (1). U situacijama ponavljanog stresa kod prevremeno rođenog novorođenčeta sa nezrelim enzimskim sistemom nabubrežne žlezde, ovaj mehanizam može biti kompromitovan, te u krajnjem dovesti do izvesnog iscrpljenja adrenalnog odgovora. 
Za situacije hroničnog stresa karakteristično je da nakon inicijalnog skoka kortizola, ako uslovi i dalje ostanu nepromenjeni, aktivnost adrenalne osovine se progresivno smanjuje i posle nekoliko sati ili dana kortizol se stabilizuje na nešto višem nivou. Tokom dugotrajnih stresnih stanja, dakle, prisutna je hiperaktivnost adrenalne osovine, što rezultira nivoom kortizola većim nego u fiziološkim situacijama, ali svakako manjim nego u patološkim stanjima ili pri kortikosteroidnoj terapiji (1).

Tako da koliko god je značajna aktivnost adrenalne osovine u stresu, gotovo podjednako je, sa druge strane, bilo eksces kortizola, ili pak hronično povišen nivo u okolnostima prematuriteta, faktor koji doprinosi razvoju patološkog stanja kod prevremeno rođenog novorođenčeta.

Osim različitih neposrednih (stres ulkus, slabije napredovanje, usporen rast, slabost veziva, osteopenija, sklonost infekcijama..) (30) od značaja su i kasne posledice stresa o kojima se sve više izveštava (metabolički sindrom, psihički poremećaji, poremećaji reproduktivne funkcije, kraći životni vek..) $(31,32,33,34)$, što nameće potrebu prevencije stresa kod prevremeno rođene dece, jer poboljšanje ishoda kod ove novorođenčadi ne treba tražiti samo u novim protokolima lečenja, već i u otklanjanju štetnih posledica tog lečenja, jer inače svi napori neće dovesti do rezultata kome se teži.

\section{Literatura}

1. Kaličanin P, Lečić Toševski D. Knjiga o stresu. Beograd: Medicinska knjiga; 1994.

2. Cvetković M. Embriogeneza i razvoj fetusa. U: Dinulović D, urednik. Opstetricija. Beograd: Službeni list SRJ; 1996. str. 264-75.

3. Seron FM, Torres C, Parraguez VH, Vergara M, Valladares L, Forcelledo ML et al. Perinatal neuroendocrine regulation. Development of the circadian time-keeping system. Mol Cell Endocrinol 2002;186:169-73.

4. Katanić D. Fetalna i neonatalna endokrinologija. Acta Medica Pediatrica 1998;2:681-92.

5. Kovačević B. Kortizolski odgovor asfiktične novorođenčadi (magistarska teza). Novi Sad (SCG): Univerzitet u Novom Sadu; 2004.

6. Đurić D, Micić D. Hipotalamusni hormoni. U: Đurić D i saradnici. Osnovi neuroendokrinologije. 2. izdanje. Beograd: Zavod za udžbenike i nastavna sredstva; 1991. str. 161-203.

7. Parker CR Jr, Buchina ES, Barefoot TK. Abnormal adrenal steroidogenesis in growth-retarded newborn infants. Pediatr Res 1994;35:633-6.

8. Radunović N. Ontogeneza neuroendokrinoloških funkcija fetusa. U: Radunović N, urednik. Novine u perinatalnoj medicini. Zbornik radova 6. simpozijuma Novine u perinatalnoj medicini; 2002 maj 16-19; Tara, Jugoslavija. Beograd: Jugoslovensko udruženje za perinatalnu medicinu; 2002. str. 22-6.

9. Economou G, Andronikou S, Challa A, Cholevas V, Lapatsanis PD. Cortisol secretion in stressed babies during the neonatal period. Horm Res 1993;40:217-21. 
10. De Zegher F, Vanhole C, Van den Berghe G, Devlieger H, Eggermont E, Veldhuis JD. Properties of thyroid-stimulating hormone and cortisol secretion by the human newborn on the day of birth. J Clin Endocrinol Metab 1994;79:576-81.

11. Hanna CE, Keith LD, Colasurdo MA, Buffkin DC, Laird MR, Mandel SH et al. Hypothalamic pituitary adrenal function in the extremely low birth weight infant. $J$ Clin Endocrinol Metab 1993;76:384-7.

12. Hawdon JM, Weddell A, Aynsley Green A, Ward Platt MP. Hormonal and metabolic response to hypoglycaemia in small for gestational age infants. Arch Dis Child 1993;68(3 Spec No):269-73.

13. Hingre RV, Gross SJ, Hingre KS, Mayes DM, Richman RA. Adrenal steroidogenesis in very low birth weight preterm infants. J Clin Endocrinol Metab 1994;78(2):266-70.

14. Wahlig TM, Gatto CW, Boros SJ, Mammel MC, Mills MM, Georgieff MK. Metabolic response of preterm infants to variable degrees of respiratory illness. $J$ Pediatr 1994; 124:283-8.

15. Bernasconi S, Ghizzoni L, Virdis R, Vanelli M, Volta C, Lamborghini A et al. Pituitary-adrenal axis response to $\mathrm{CRH}$ in childhood: clinical aspects. In: Stress and related disorders. Abstracts of the International Congress on stress and related disorders: from adaptation to dysfunction; 1990 Nov 18-21; Modena, Italy. p. 45.

16. Scott SM, Watterberg KL. Effect of gestational age, postnatal age, and illness on plasma cortisol concentrations in premature infants. Pediatr Res 1995;37:112-6.

17. Ruth V, Hallman M, Laatikainen T. Corticotropin-releasing hormone and cortisol in cord plasma in relation to gestational age, labor, and fetal distress. Am J Perinatol 1993;10:115-8.

18. Tomaževič F. Kortizol v popkovni plazmi ob rojstvu ploda v medenični vstavi (magistarsko delo). Ljubljana (YU): Univerza "Edvarda Kardelja” v Ljubljani; 1982.

19. Taylor A, Fisk NM, Glover V. Mode of delivery and subsequent stress response. Lancet 2000;355:120.

20. Gitau R, Menson E, Pickles V, Fisk NM, Glover V, MacLachlan N. Umbilical cortisol levels as an indicator of the fetal stress response to assisted vaginal delivery. Eur $\mathrm{J}$ Obstet Gynecol Reprod Biol 2001;98:14-7.

21. Al Saedi S, Dean H, Dent W, Cronin C. Reference ranges for serum cortisol and 17 hydroxyprogesterone levels in preterm infants. J Pediatr 1995;126:985-97.

22. Heckmann M, Wudy SA, Haack D, Pohlandt F. Reference range for serum cortisol in well preterm infants. Arch Dis Child Fetal Neonatal Ed 1999;81:F171-4.

23. Masumoto K, Kusuda S, Aoyagi H, Tamura Y, Obonai T, et al. Comparison of serum cortisol concentrations in preterm infants with or without late-onset circulatory collapse due to adrenal insufficiency of prematurity. Pediatr Res 2008; 63(6):686-90.

24. Bolt RJ, Van Weissenbruch MM, Popp-Snijders C, Sweep FG, Lafeber HN, Delemarre-van de Waal HA. Maturity of the adrenal cortex in very preterm infants is related to gestational age. Pediatr Res 2002;52(3):405-10.

25. Ng PC, Lam CWK, Fok TF, et al. Refractory hypotension in preterm infants with adrenocortical insufficiency. Arch Dis Child Fetal Neonatal Ed 2001;84(2):F122-F124. 
26. Ng PC, Lam CWK, Lee $\mathrm{CH}$, et al. Reference ranges and factors affecting the hCRH test in preterm, very low birth weight infants. J Clin Endocrinol Metab 2002;87(10):4621-8

27. Ng PC, Lee CH, Lam CWK, et al. Transient adrenocortical insufficiency of prematurity and systemic hypotension in very low birthweight infants. Arch Dis Child Fetal Neonatal Ed 2004;89(2):F119-F126.

28. Wittekind CA, Arnold JD, Leslie GI, Luttrell B, Jones MP. Longitudinal study of plasma ACTH and cortisol in very low birth weight infants in the first 8 weeks of life. Early Hum Dev 1993;33:191-200.

29. Watterberg K. Fetal adrenal development - Implications for lung development and postnatal disease. NeoReviews 2006;7:e135-42.

30. Kovačević B. Mogućnost predviđanja neonatalnog ishoda kod dece veoma male telesne mase na rođenju na osnovu nivoa kortizola (doktorska disertacija). Novi Sad (SRB): Univerzitet u Novom Sadu; 2012.

31. Phillips DI, Walker BR, Reynolds RM, Flanagan DE, Wood PJ, Osmond C, Barker DJ, Whorwood CB. Low birth weight predicts elevated plasma cortisol concentrations in adults from 3 populations. Hypertension 2000;35(6):1301-6.

32. Smith GC, Gutovich J, Smyser C, Pineda R, Newnham C, Tjoeng TH, Vavasseur $\mathrm{C}$, Wallendorf M, Neil J, Inder T. Neonatal intensive care unit stress is associated with brain development in preterm infants. Ann Neurol 2011;70(4):541-9.

33. Marrama P, Merlo Pich E, Biagini G, Vecchi M, Carani C, Agnati LF. Effects of stress on intra-testicular regulatory mechanisms. In: Stress and related disorders. Abstracts of the International Congress on stress and related disorders: from adaptation to dysfunction; 1990 Nov 18-21; Modena, Italy. p. 91

34. Cota BM, Allen PJ. The developmental origins of health and disease hypothesis. Pediatr Nurs 2010;36(3):157-67. 